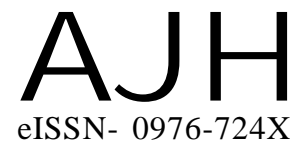

Received : 27.02.2017

Revised : 28.04.2017

Accepted : 12.05.2017
Members of the Research Forum

Associated Authors:

${ }^{1}$ Department of Plant Breeding and Genetics, Agricultural College and Research Institute, Madurai (T.N.) India ${ }^{2}$ Department of Fruits, Horticultural College and Research Institute, PERIYAKULAM (T.N.) INDIA

Author for correspondence

M. I. MANIVANNAN

ICAR-Krishi Vigyan Kendra,

THIRUPATHISARAM (T.N.) INDIA
THEASIAN JOURNAL OF HORTICULTURE

Volume 12 | Issue $1 \mid$ June, 2017 | 79-83

Visit us -www.researchjournal.co.in

RESEARCH PAPER

DOI : 10.15740/HAS/TAJH/12.1/79-83

\section{Genotype $\mathrm{x}$ environment interaction and stability analysis for fruit yield and quality traits in pineapple (Ananas comosus)}

\section{M.I. MANIVANNAN, G. ANAND ${ }^{1}$ AND S. IRULANDI ${ }^{2}$}

ABSTRACT : The present study was conducted to assess the existence of genotype $\mathrm{x}$ environmental ( $\mathrm{G}$ x E) interactions and stability for yield and quality related traits in pineapple using four varieties over seven locations during the year 2012-13. Pooled analysis of variance over seven locations revealed that the genotypic variances were highly significant for all the characters which revealed considerable genetic variability in the population. Stability parameters revealed that the genotype 'Amritha' was found better under poor environments. 'Mauritius' and 'Amritha' showed stable and consistent performance for all quantitative and qualitative traits whereas, 'Mauritius' had above average response and high stability in better environments for yield only. Thus, genotypes 'Amritha' and 'Mauritius' may be utilized in hybrid breeding programme to exploit their consistent performance in all order of yield.

KEY WORDS : Genotype x environment interaction, Stability, Quality, Yield

HOW TO CITE THIS ARTICLE : Manivannan, M.I., Anand, G. and Irulandi, S. (2017). Genotype x environment interaction and stability analysis for fruit yield and quality traits in pineapple (Ananas comosus ). Asian J. Hort., 12(1) : 79-83, DOI : 10.15740/HAS/TAJH/12.1/79-83. 